\title{
Dietary Effect of $\gamma$-Linolenic Acid on the Lipid Profile of Rat Fed Erucic Acid Rich Oil
}

\author{
Sayantani Dasgupta ${ }^{1}$ and Dipak Kumar Bhattacharyya ${ }^{2 *}$ \\ ${ }^{1}$ Berhampore Girls' College, Berhampore, Murshidabad, West Bengal, INDIA \\ ${ }^{2}$ Department of Chemical Technology, University of Calcutta, University Colleges of Science \& Technology, 92, A.P.C. Road, Kolkata \\ 700009, INDIA
}

\begin{abstract}
This study evaluated the effects of dietary supplementation of $\gamma$-Linolenic acid (18:3n-6, GLA) on the lipid profile of serum and other tissues of rats fed erucic acid (C22:1) rich oil like mustard oil. The rats were fed diet containing $20 \%$ mustard oil as erucic acid rich oil and $20 \%$ groundnut oil as dietary fat. These groups were kept as reference groups. Another group fed diet containing $20 \%$ fat to which evening primrose oil as a source of GLA was blended with mustard oil and groundnut oil at $5 \%$ level. The feeding experiment was done for 4 weeks. In another set mustard oil fed group was kept as control while the experimental group was fed evening primrose oil as a source of GLA blended with mustard oil at $2.5 \%$ level. The feeding experiment was carried out for 12 weeks. The other dietary components remained same for all the groups. After the scheduled feeding period, it was found that there was no significant change in weight gain, food intake and food efficiency ratio. It was found that dietary GLA resulted in significant decrease in serum triglyceride (TG) and very low density lipoprotein (VLDL) cholesterol and significant increase in high density lipoprotein (HDL) cholesterol in serum in the experimental group. In liver total cholesterol (TC) is significantly higher and in heart and liver TG is significantly lower in GLA fed group.
\end{abstract}

Key words: $\gamma$-Linolenic acid, erucic acid, mustard oil

\section{INTRODUCTION}

Mustard oil which is a traditional edible oil in most part of India is a rich source of erucic acid. The two essential fatty acids, namely, linoleic and linolenic occur in mustard oil but high levels of erucic acid (C22:1) present in mustard oil may compromise some of the beneficial effect of linoleic $(18: 2 n-6)$ and $\alpha$ linolenic acids $(18: 3 n-3)^{1)}$. There is report that erucic acid rich oil may cause cardiac lipidosis by accumulation of substantial fat in the heart muscle ${ }^{2)}$. It is not known precisely whether the two essential fatty acids namely linolenic and linoleic acid as occurring in mustard oil in nearly equal proportions and totalling $25-30 \%$ are inadequate or it is necessary to add other polyunsaturated fatty acid (PUFA) to counteract lipidosis (platelet aggregation and myocardial infarction) such as $\gamma$-Linolenic acid (GLA,18:3n-6), that is recognised for its food and pharmaceutical value. In humans and other mammals it is preessential fatty acid. GLA is a precursor of prostaglandins and also is essential for patients who suffer from diabetes, cancer, aging and viral infection ${ }^{3-5)}$. GLA rich acyl glycerides have been applied directly in the treatment of certain skin related and other diseases such as multiple sclerosis ${ }^{6)}$, rheumatoid arthritis ${ }^{7)}$ and pre-menstrual syndrome ${ }^{8)}$.

In order to examine the effect of GLA on erucic acid rich oil, two sets of experiments were conducted, one was short term study with higher dose of GLA and the other was long term study with lower dose of GLA. The variation in the dose and duration of the study was done to examine whether there is any variation in the effect in respect of dose with short or prolonged study. Groundnut oil is also a major edible oil in India. It is rich in oleic acid (C18:1) which is also a monoethenoid acid having 4 carbon atoms less than monoethenoid erucic acid. Groundnut oil fed group was kept as another control to observe whether there is similarity in the effect as in mustard oil fed group.

* Correspondence to: Dipak Kumar Bhattacharyya, Department of Chemical Technology, University of Calcutta, University Colleges of Science \& Technology 92, A.P.C. Road, Kolkata 700009, INDIA

E-mail: dkb_oiltech@rediffmail.com

Accepted August 7, 2007 (received for review May 28, 2007)

Journal of Oleo Science ISSN 1345-8957 print / ISSN 1347-3352 online

http://jos.jstage.jst.go.jp/en/ 


\section{S. Dasgupta and D.K. Bhattacharyya}

The aim of the present study is to investigate the dietary effects of PUFA such as GLA on the dietary erucic acid as occurring in mustard oil in relation to lipidemic effect [total cholesterol (TC), low density lipoprotein (LDL)cholesterol, high density lipoprotein (HDL)-cholesterol, very low density lipoprotein (VLDL) - cholesterol, triglyceride (TG)] of serum and other tissues. It is not known whether the GLA as occurring in evening primrose oil is helpful in overcoming the shortcomings of erucic acid cited above by manipulation of lipid profile like TC, LDL, HDL, VLDL, TG etc.

\section{EXPERIMENTAL}

\subsection{Materials}

Mustard Oil: Engine Agmark Grade-1 Mustard Oil of Hari Vegetable Products Private Limited, Mal Godown Road, Bharatpur 321001, Rajasthan, India was used.

Evening Primrose Oil: The source of GLA is evening primrose oil available in capsule form as Primosa manufactured by Banner Pharmacaps (India) Pvt. Ltd., Yadavanahalli, Attibelle, Bangalore, Hosur Road, Bangalore 562107, Marketed by Universal Medicare Limited, Sion-Trombay Road, Deonar, Mumbai 400088.

Groundnut Oil: Manufactured by Kamani Oil Industries Prop. Chawla Bros. Ltd. Chandivali Estate, Saki Vihar Road Sakinaka, Mumbai-400072. Marketed by Cargill foods, Cargill India Pvt. Ltd. DLF Gateway Towers, DlF City; Phase III Gurgaon 122002 Haryana.

\subsection{Analysis of fat products}

Gas-liquid chromatography was employed for determining the fatty acid composition of the dietary oils after their conversion into methyl esters by $\mathrm{BF}_{3}$ methanol ${ }^{9)}$.

\subsection{Blending of oils}

Blending of evening primrose oil (EPO) as the source of GLA with mustard oil (MO) was done at 2.5\% and 5\% level and with groundnut oil (GNO) was done at $5 \%$ level.

\subsection{Feeding experiment}

Experimental animals and diets: The animal experiment was designed based on earlier reports published from this laboratory ${ }^{10)}$. Male Albino rats (Charles Foster Strain) weighing an average of $60 \mathrm{gm}$ were housed individually in stainless steel cages with mesh floors in a room maintained under constant temperature $\left(20-25^{\circ} \mathrm{C}\right)$ and a $10 \mathrm{~h}$ light/14 h dark cycle (appropriate light and dark cycle is responsible to maintain the biological rhythm which maintains hormonal cycles which inturn controls the lipid metabolism). Following a 10 day adaptation during which the animals were maintained on a standard diet ${ }^{10)}$ and water ad libitum, rats were divided into four groups of 8 rats per group. Two groups were considered to be control ( $\mathrm{MO}$ and $\mathrm{GNO}$ ) and two groups were experimental $\mathrm{MO}$ $(95 \%)+\mathrm{EPO}(5 \%)$ and GNO (95\%) + EPO (5\%). The feeding experiment was carried out for four weeks. In another set $\mathrm{MO}$ fed group kept as control while the experimental group fed EPO blended with MO at 2.5\% level. The feeding experiment was carried out for twelve weeks. Food intake was measured daily while growth of the animals was monitored once a week.

Each group of rat received different dietary oil while the other dietary components were same. Carbohydrate was supplied by starch (I.P. grade) which contributed 55\% of the diet $18 \%$ of the diet derived from casein, cellulose which contributed to $3 \%$ of the diet. $4 \%$ of the diet was derived from ash, which was supplied by salt mixture, (composition of saltmixture No.12 (in g): $\mathrm{NaCl} 292.5$, $\mathrm{KH}_{2} \mathrm{PO}_{4}$ 816.6; $\mathrm{MgSO}_{4}$ 120.3; $\mathrm{CaCO}_{3}$ 800.8; $\mathrm{FeSO}_{4}, 7 \mathrm{H}_{2} \mathrm{O}$ 56.6; $\mathrm{KI}$ 1.66; $\mathrm{MnSO}_{4}$. $2 \mathrm{H}_{2} \mathrm{O}, 9.35 ; \mathrm{ZnCl}_{2}$ 0.5452; $\mathrm{CuSO}_{4}$. $5 \mathrm{H}_{2} \mathrm{O}$, $0.9988, \mathrm{CoCl}_{2} 6 \mathrm{H}_{2} \mathrm{O} 0.0476^{11)}$. Total $20 \%$ fat and $0.01 \mathrm{~g}$ of vitamin capsule (Vitamin A I.P. 10000 units, Thiamine mononitrate I.P. $5 \mathrm{mg}$, Vitamin B I.P. $5 \mathrm{mg}$, Calcium pantothenate USP $5 \mathrm{mg}$, Niacinamide I.P. $50 \mathrm{mg}$, Ascorbic acid I.P. 400 units, Cholecalciferol USP 15 units, Menadione I.P. $9.1 \mathrm{mg}$, Folic acid I.P. $1 \mathrm{mg}$, Vitamin E USP $0.1 \mathrm{mg}$ ) were also included in the diet.

The Food Efficiency Ratio (FER) for each rat was calculated by the following equation.

FER = Body weight gain / Food consumed.

At the end of 4 weeks and 12 weeks experimental period, $14 \mathrm{~h}$ fasted rats were subjected to a light anaesthesia using chloroform. The abdomen was opened, blood samples were collected from the hepatic vein in the presence of heparin and centrifuged at low speed $(3000 \times \mathrm{g})$ to isolate the plasma. Liver, heart and brain were also collected, cleaned by washing with saline $(0.9 \%)$ and blotted dry with blotting paper. The weights of the tissues were noted, samples were stored at $-30^{\circ} \mathrm{C}$ until subsequent extraction of tissue lipids.

\subsection{Lipid analysis}

Total lipids were extracted from the liver, heart, and brain with a chloroform methanol mixture and estimated gravimetrically ${ }^{12)}$. Small pieces of freshly dissected tissue were taken in a homogenizer and mixed with $3 \mathrm{ml}$ of water and $30 \mathrm{ml}$ of methanol- chloroform mixture $(2: 1, \mathrm{v} / \mathrm{v})$. The tissue was homogenized at room temperature. The homogenate was then centrifuged at $3000 \mathrm{rpm}$ for $10 \mathrm{~min}$ utes at room temperature and the supernatant was collected in a separating funnel. The residue was again homogenized with methanol-chloroform-water $(2: 1: 0.8, \mathrm{v} / \mathrm{v} / \mathrm{v})$ and again centrifuged at $3000 \mathrm{rpm}$ for 10 minutes at room temperature. The supernatant was collected in the same separating funnel. The content in the funnel was diluted with $20 \mathrm{ml}$ of both chloroform and water. The mixture was 
allowed to stand for sometime so that complete separation of chloroform layer took place. The chloroform layer was collected quantitatively and solvent was evaporated under vacuum. The total lipid extracted from different tissues such as liver, heart and brain were weighed and the residue was dissolved in known volume of fresh chloroform (BDH, A.R quality) and nitrogen was bubbled through it. Then it was stored in a deep fridge $\left(-40^{\circ} \mathrm{C}\right)$ until further analysis.

According to the standard enzymatic methods, the lipid components such as $\mathrm{TC}^{13)}$, $\mathrm{HDL}^{14)}, \mathrm{LDL}^{15)}, \mathrm{VLDL}^{16)}$ and $\mathrm{TG}^{17)}$ of the plasma were determined. Using the same methodologies, TC, TG and phospholipids ${ }^{18)}$ of the liver, heart and TC and phospholipids of the brain were determined.

\subsection{Statistical analysis}

Data from the nutrition study were analysed using the student ' $t$ ' test ${ }^{19)}$. Significance was accepted at $\mathrm{p} \leq 0.05$.

\section{RESULTS}

\subsection{Fatty acid composition}

The fatty acid composition of the MO, GNO and EPO which was used for the source of GLA are shown in Table 1.

\subsection{Growth rate}

Table 2 and 3 indicate the growth response and food intake, FER of rats fed mustard oil and MO (95\%) + EPO (5\%) at the end of 4 weeks. Table 4 and 5 indicate the growth response and food intake, FER of rats fed GNO and GNO (95\%) + EPO (5\%) at the end of 4 weeks. Table 6 and 7 indicates the growth response and food intake, FER of rats fed MO and MO (97.5\%) + EPO (2.5\%) at the end of 12 weeks. These tables indicate that there is no significant change in growth response and FER of the experimental group in comparison with the control group.

\subsection{Lipid profile}

Table 8 shows the lipid profile of the serum of the rats fed $\mathrm{MO}$ and GNO along with EPO at 5\% level for 4 weeks. There is significant decrease in TG and VLDL and signifi-

Table 1 Fatty Acid Composition of MO, GNO and EPO Containing GLA.

\begin{tabular}{|l|c|c|c|c|c|c|}
\hline \multirow{2}{*}{ Fatty Acids } & \multicolumn{7}{|c|}{$\%(\mathrm{w} / \mathrm{w})$} \\
\cline { 2 - 7 } & MO & GNO & EPO & $\begin{array}{l}\text { MO (95\%) } \\
\text { EPO (5\%) }\end{array}$ & $\begin{array}{l}\text { GNO (95\%) } \\
\text { EPO (5\%) }\end{array}$ & $\begin{array}{l}\text { MO (97.5\%) } \\
\text { EPO }(2.5 \%)\end{array}$ \\
\hline Palmitic acid (16:0) & 2.04 & 14.43 & 6.10 & 2.24 & 14.01 & 2.14 \\
\hline Stearic acid (18:0) & - & 3.26 & 1.24 & 0.06 & 3.159 & 0.03 \\
\hline Oleic acid (18:1) & 12.00 & 54.66 & 6.67 & 11.73 & 52.26 & 11.866 \\
\hline Linoleic acid (18:2) & 16.60 & 26.81 & 74.05 & 19.47 & 29.17 & 18.036 \\
\hline $\begin{array}{l}\text { Linolenic acid } \\
(18: 3)(n-3)\end{array}$ & 20.43 & - & - & 19.408 & - & 19.919 \\
\hline $\begin{array}{l}\text { Linolenic acid } \\
(18: 3)(n-6)\end{array}$ & & & $11.94(\gamma)$ & 0.597 & 0.597 & 0.298 \\
\hline Erucic acid (22:1) & 48.18 & - & - & 45.77 & - & 46.975 \\
\hline
\end{tabular}

Table 2 Mean Body Weight Gain of Rats Fed MO and MO (95\%) + EPO (5\%) at the End of 4 Week.

\begin{tabular}{|lcccc|}
\hline \multicolumn{5}{c|}{ Average Weight Gain $(\mathrm{g}) /$ Week } \\
Dietary Fat Groups & I & II & III & IV \\
\hline MO & $19.33 \pm 2.11$ & $32.33 \pm 2.94$ & $42.00 \pm 3.14$ & $51.33 \pm 3.49$ \\
MO + EPO & $21.33 \pm 2.23$ & $30.67 \pm 3.92$ & $41.33 \pm 2.86$ & $52.00 \pm 2.13$ \\
\hline
\end{tabular}

Values are mean \pm S.E.M, $n=6$ 


\section{S. Dasgupta and D.K. Bhattacharyya}

Table 3 Food Intake and FER of Rats fed MO and MO (95\%) + EPO (5\%) at the End of 4 Week.

\begin{tabular}{|lcccc|}
\hline & \multicolumn{4}{c|}{ Food Intake } \\
Dietary Fat Groups & I & II & III & IV \\
\hline MO & $58.00 \pm 2.99$ & $123.66 \pm 4.02$ & $185.66 \pm 5.42$ & $253.66 \pm 5.78$ \\
MO + EPO & $63.33 \pm 0.56$ & $130.00 \pm 0.36$ & $196.00 \pm 0.97$ & $264.33 \pm 0.92$ \\
\hline
\end{tabular}

\begin{tabular}{|lcccc|}
\hline & \multicolumn{3}{c|}{ FER } \\
Dietary Fat Groups & I & II & III & IV \\
\hline MO & $0.28 \pm 0.020$ & $0.27 \pm 0.036$ & $0.23 \pm 0.026$ & $0.21 \pm 0.020$ \\
MO + EPO & $0.31 \pm 0.037$ & $0.24 \pm 0.027$ & $0.23 \pm 0.012$ & $0.20 \pm 0.009$ \\
\hline
\end{tabular}

Values are mean \pm S.E.M, $n=6$

Table 4 Mean Body Weight Gain Versus Week of Rats fed GNO and GNO (95\%) + EPO (5\%) at the End of 4 Week.

\begin{tabular}{|lcccc|}
\hline \multicolumn{4}{c}{ Average Weight Gain (g)/ Week } & \\
Dietary Fat Groups & I & II & III & IV \\
\hline GNO & $22.33 \pm 1.58$ & $37.33 \pm 3.08$ & $59.67 \pm 3.63$ & $74.33 \pm 3.59$ \\
GNO + EPO & $21.33 \pm 3.17$ & $30.00 \pm 1.79$ & $47.3 \pm 3.78^{* a}$ & $63.33 \pm 4.18$ \\
\hline
\end{tabular}

Values are mean \pm S.E.M, $n=6$

a control group fed GNO Vs GNO + EPO

* $\mathrm{P}<0.05$

Table 5 Food Intake and FER of Rats fed GNO and GNO (95\%) + EPO (5\%) at the end of 4 Week.

\begin{tabular}{|lcccc|}
\hline & \multicolumn{4}{c|}{ Food Intake } \\
Dietary Fat Groups & I & II & III & IV \\
\hline GNO & $68.00 \pm 0.97$ & $132.67 \pm 0.92$ & $199.67 \pm 1.47$ & $266.00 \pm 1.67$ \\
GNO + EPO & $67.50 \pm 0.22$ & $132.00 \pm 0.45$ & $196.00 \pm 1.34$ & $263.00 \pm 0.89$ \\
\hline
\end{tabular}

\begin{tabular}{|lcccc|}
\hline & \multicolumn{4}{c|}{ FER } \\
Dietary Fat Groups & I & II & III & IV \\
\hline GNO & $0.328 \pm 0.009$ & $0.25 \pm 0.022$ & $0.30 \pm 0.015$ & $0.28 \pm 0.009$ \\
GNO + EPO & $0.27 \pm 0.029$ & $0.27 \pm 0.012$ & $0.25 \pm 0.017^{* a}$ & $0.24 \pm 0.016$ \\
\hline
\end{tabular}

Values are mean \pm S.E.M, $n=6$

a control group fed GNO Vs GNO + EPO

* $\mathrm{P}<0.05$

cant increase in LDL in case of the rats fed $\mathrm{MO}+\mathrm{EPO}$ when compared with the rats fed MO. There is also increase in case of HDL when compared between the above two groups. There is also significant decrease in TC, TG, VLDL, LDL and significant increase in HDL in case of
$\mathrm{GNO}+\mathrm{EPO}$ fed group.

Table 9 shows the lipid profile of liver, heart and brain among the groups fed $\mathrm{MO}$ and $\mathrm{MO}+\mathrm{EPO}$ and GNO and $\mathrm{GNO}+\mathrm{EPO}$. There is significant decrease in TG content of the liver and heart in the groups fed $\mathrm{MO}+\mathrm{EPO}$ when 
Table 6 Mean Body Weight Gain of the Rats Fed MO and MO (97.5\%) + EPO (2.5\%) at the End of Different Weeks.

\begin{tabular}{|c|c|c|c|c|c|c|c|c|c|c|c|c|}
\hline \multirow{2}{*}{$\begin{array}{l}\text { Dietary } \\
\text { Fat } \\
\text { Group }\end{array}$} & \multicolumn{12}{|c|}{ Average Weight Gain (g) / Week } \\
\hline & I & II & III & IV & $\mathrm{V}$ & VI & VII & VIII & IX & $\mathrm{X}$ & $\mathrm{XI}$ & XII \\
\hline MO & $\begin{array}{l}17.66 \\
\pm 0.61\end{array}$ & $\begin{array}{l}26.00 \\
\pm 0.89\end{array}$ & $\begin{array}{l}37.50 \\
\pm 0.96\end{array}$ & $\begin{array}{l}46.50 \\
\pm 1.26\end{array}$ & $\begin{array}{l}50.50 \\
\pm 1.26\end{array}$ & $\begin{array}{l}55.50 \\
\pm 1.50\end{array}$ & $\begin{array}{l}64.50 \\
\pm 1.89\end{array}$ & $\begin{array}{l}65.50 \\
\pm 1.50\end{array}$ & $\begin{array}{l}70.00 \\
\pm 2.00\end{array}$ & $\begin{array}{l}77.00 \\
\pm 2.51\end{array}$ & $\begin{array}{l}79.00 \\
\pm 2.08\end{array}$ & $\begin{array}{l}78.50 \\
\pm 1.71\end{array}$ \\
\hline $\begin{array}{l}\mathrm{MO}+ \\
\mathrm{EPO}\end{array}$ & $\begin{array}{l}20.50 * \mathrm{a} \\
\pm 1.26\end{array}$ & $\begin{array}{l}26.50 \\
\pm 1.89\end{array}$ & $\begin{array}{l}33.50 \\
\pm 1.71\end{array}$ & $\begin{array}{l}34.50 * * * \mathrm{a} \\
\pm 1.26\end{array}$ & $\begin{array}{l}41.50 * * * \mathrm{a} \\
\pm 0.96\end{array}$ & $\begin{array}{l}46.00^{* * * a} \\
\pm 1.41\end{array}$ & $\begin{array}{l}49.00 * * * a \\
\pm 1.29\end{array}$ & $\begin{array}{l}56.50 * * a \\
\pm 1.71\end{array}$ & $\begin{array}{l}64.50 \\
\pm 2.63\end{array}$ & $\begin{array}{l}68.00^{* \mathrm{a}} \\
\pm 1.91\end{array}$ & $\begin{array}{l}69.00 * * a \\
\pm 1.91\end{array}$ & $\begin{array}{l}70.05^{* * a} \\
\pm 0.96\end{array}$ \\
\hline
\end{tabular}

Values are mean \pm S.E.M, $n=6$

${ }^{\text {a }}$ Control group fed MO Vs MO + EPO

$* \quad \mathrm{P}<0.05$

** $\quad \mathrm{P}<0.01$

$* * * \mathrm{P}<0.001$

Table 7 Food Intake and FER of the Rats Fed MO and MO (97.5\%) + EPO (2.5\%) at the End of Different Weeks.

\begin{tabular}{|c|c|c|c|c|c|c|c|c|c|c|c|c|}
\hline $\begin{array}{l}\text { Dietary } \\
\text { Fat }\end{array}$ & \multicolumn{12}{|c|}{ Food Intake } \\
\hline & I & II & III & IV & $\mathrm{V}$ & VI & VII & VIII & IX & $X$ & XI & XII \\
\hline MO & $\begin{array}{l}51.00 \\
\pm 1.73\end{array}$ & $\begin{array}{l}104.67 \\
\pm 0.99\end{array}$ & $\begin{array}{l}157.00 \\
\pm 1.29\end{array}$ & $\begin{array}{l}204.50 \\
\pm 2.87\end{array}$ & $\begin{array}{l}249.50 \\
\pm 3.94\end{array}$ & $\begin{array}{l}302.00 \\
\pm 4.24\end{array}$ & $\begin{array}{l}362.00 \\
\pm 3.55\end{array}$ & $\begin{array}{l}426.00 \\
\pm 1.82\end{array}$ & $\begin{array}{l}476.00 \\
\pm 5.71\end{array}$ & $\begin{array}{l}530.00 \\
\pm 4.32\end{array}$ & $\begin{array}{l}588.50 \\
\pm 5.19\end{array}$ & $\begin{array}{l}652.00 \\
\pm 2.70\end{array}$ \\
\hline $\begin{array}{l}\mathrm{MO}+ \\
\mathrm{EPO}\end{array}$ & $\begin{array}{l}55.00 \\
\pm 1.52\end{array}$ & $\begin{array}{l}100.67 \\
\pm 1.91\end{array}$ & $\begin{array}{l}143.67^{* * a} \\
\pm 2.98\end{array}$ & $\begin{array}{l}196.67 \\
\pm 2.67\end{array}$ & $\begin{array}{l}242.67 \\
\pm 3.00\end{array}$ & $\begin{array}{l}294.67 \\
\pm 5.55\end{array}$ & $\begin{array}{l}337.00 * a \\
\pm 7.88\end{array}$ & $\begin{array}{l}416.00 \\
\pm 9.31\end{array}$ & $\begin{array}{l}438.00 * * a \\
\pm 9.83\end{array}$ & $\begin{array}{l}493.00 * \mathrm{a} \\
\pm 11.21\end{array}$ & $\begin{array}{l}563.67 \\
\pm 12.07\end{array}$ & $\begin{array}{l}592.67^{* * a} \\
\pm 13.36\end{array}$ \\
\hline
\end{tabular}

\begin{tabular}{|c|c|c|c|c|c|c|c|c|c|c|c|c|}
\hline $\begin{array}{l}\text { Dietary } \\
\text { Fat }\end{array}$ & \multicolumn{12}{|c|}{ FER } \\
\hline & I & II & III & IV & $\mathrm{V}$ & VI & VII & VIII & IX & $X$ & XI & XII \\
\hline MO & $\begin{array}{l}0.33 \\
\pm 0.29\end{array}$ & $\begin{array}{l}0.19 \\
\pm 0.021\end{array}$ & $\begin{array}{l}0.20 \\
\pm 0.02\end{array}$ & $\begin{array}{l}0.15 \\
\pm 0.01\end{array}$ & $\begin{array}{l}0.14 \\
\pm 0.007\end{array}$ & $\begin{array}{l}0.13 \\
\pm 0.014\end{array}$ & $\begin{array}{l}0.13 \\
\pm 0.015\end{array}$ & $\begin{array}{l}0.12 \\
\pm 0.008\end{array}$ & $\begin{array}{l}0.12 \\
\pm 0.01\end{array}$ & $\begin{array}{l}0.09 \\
\pm 0.005\end{array}$ & $\begin{array}{l}0.09 \\
\pm 0.006\end{array}$ & $\begin{array}{l}0.10 \\
\pm 0.007\end{array}$ \\
\hline $\begin{array}{l}\mathrm{MO}+ \\
\mathrm{EPO}\end{array}$ & $\begin{array}{l}0.33 \\
\pm 0.04\end{array}$ & $\begin{array}{l}0.17 \\
\pm 0.01\end{array}$ & $\begin{array}{l}0.129 * * a \\
\pm 0.013\end{array}$ & $\begin{array}{l}0.145 \\
\pm 0.010\end{array}$ & $\begin{array}{l}0.122 \\
\pm 0.0087\end{array}$ & $\begin{array}{l}0.117 \\
\pm 0.011\end{array}$ & $\begin{array}{l}0.096 \\
\pm 0.006\end{array}$ & $\begin{array}{l}0.107 \\
\pm 0.0069\end{array}$ & $\begin{array}{l}0.105 \\
\pm 0.009\end{array}$ & $\begin{array}{l}0.109 \\
\pm 0.005\end{array}$ & $\begin{array}{l}0.087 \\
\pm 0.007\end{array}$ & $\begin{array}{l}0.086 \\
\pm 0.004\end{array}$ \\
\hline
\end{tabular}

Values are mean \pm S.E.M, $\mathrm{n}=6$

${ }^{\mathrm{a}}$ Control group fed MO Vs MO + EPO

* $\mathrm{P}<0.02$

** $\mathrm{P}<0.01$

compared with MO fed group. There is no significant change in case of brain lipid profile. There is significant decrease in liver total lipid PL and TG and increase in TC in the groups fed GNO with EPO when compared with GNO fed group. In case of the heart there is significant decrease in TC and TG in the experimental group. In brain significant decrease in total lipid and increase in phospholipids observed in the experimental group when compared with the control group.

Mean plasma TC, TG, HDL, LDL, VLDL of rats fed MO and $\mathrm{MO}+\mathrm{EPO}$ at the reduced level of $2.5 \%$ for 12 weeks are listed in Table 10. Data indicate that there is no significant change in TC and LDL compared to control group. There is significant decrease in serum TG and VLDL and significant increase in HDL in case of experimental group. The changes in the tissue lipid profile are enlisted in Table 


\section{S. Dasgupta and D.K. Bhattacharyya}

Table 8 Lipid Concentrations of Serum of the Rats Fed MO, MO (95\%) + EPO (5\%) and GNO, GNO (95\%) + EPO (5\%) Level at the End of 4 Weeks.

\begin{tabular}{|l|c|c|c|c|}
\hline & MO & MO + EPO & GNO & GNO + EPO \\
\hline $\begin{array}{l}\text { Total Cholesterol } \\
(\mathrm{mg} / \mathrm{dl})\end{array}$ & $73.79 \pm 4.64$ & $82.34 \pm 1.14$ & $78.07 \pm 2.51$ & $61.84 \pm 3.38^{* * \mathrm{~b}}$ \\
\hline Triglyceride (mg/dl) & $100.25 \pm 3.74$ & $62.73 \pm 3.73^{* \mathrm{a}}$ & $96.50 \pm 1.79$ & $62.75 \pm 2.67^{* \mathrm{~b}}$ \\
\hline $\begin{array}{l}\text { HDL cholesterol } \\
(\mathrm{mg} / \mathrm{dl})\end{array}$ & $37.74 \pm 3.62$ & $40.05 \pm 1.72$ & $30.87 \pm 1.84$ & $39.20 \pm 3.00^{\mathrm{b} * * * \mathrm{~b}}$ \\
\hline $\begin{array}{l}\text { VLDL cholesterol } \\
(\mathrm{mg} / \mathrm{dl})\end{array}$ & $20.05 \pm 0.75$ & $12.54 \pm 0.75^{* \mathrm{a}}$ & $19.30 \pm 0.36$ & $12.55 \pm 0.53^{* \mathrm{~b}}$ \\
\hline $\begin{array}{l}\text { LDL cholesterol } \\
(\mathrm{mg} / \mathrm{dl})\end{array}$ & $15.86 \pm 3.60$ & $29.75 \pm 2.26^{* * \mathrm{a}}$ & $27.89 \pm 0.85$ & $10.08 \pm 1.14^{* \mathrm{~b}}$ \\
\hline
\end{tabular}

Value are mean \pm SEM, $\mathrm{n}=6$

${ }^{\text {a }}$ control group fed MO Vs MO + EPO.

${ }^{\mathrm{b}}$ control group fed GNO Vs GNO + EPO.

* $\mathrm{p}<0.001$

$* * \quad \mathrm{p}<0.01$

$* * * \mathrm{p}<0.05$

11. The data indicate in case of liver significant rise in TC of EPO fed group. In heart significant decrease in TG was found in EPO fed group. Significant decrease in TC of brain was also found in EPO fed group.

\section{DISCUSSION}

The primary purpose of the present study was to obtain an idea about the effect of dietary GLA on the lipid profile of the rats fed erucic acid rich oil like MO. There is no significant change in weight gain, food intake, and FER of the rats fed $\mathrm{MO}(95 \%)+\mathrm{EPO}(5 \%)$ and $\mathrm{GNO}(95 \%)+\mathrm{EPO}(5 \%)$ in comparison with the MO and GNO fed group for 4 weeks. There is also no significant change in weight gain, food intake, and FER of the rats fed MO (97.5\%) + EPO (2.5\%) in comparison with the MO fed group for 12 weeks. Results showed significant decrease in serum TG and VLDL and significant increase in HDL in experimental group which is a good indication for health. Liver lipid profile shows significant decrease in TG and increase in TC in GLA fed group. In heart significant decrease in TG was observed in the experimental group.

$\mathrm{EPO}+\mathrm{MO}$ (with high erucic acid) and high oleic acid rich GNO, provides beneficial effects like the reduction of TG and VLDL and elevation of HDL cholesterol in serum. When EPO (5\% \& 2.5\%) blended with $\mathrm{MO}$ and given to the rats for 4 weeks and 12 weeks respectively the same effect was found on the above parameters. When EPO is blended with GNO (5\%) the level of LDL is reduced but when blended with MO the level of LDL is high. This elevation in the level of LDL may be due to the presence of high level of erucic acid present in $\mathrm{MO}$. Oleic acid present in GNO and erucic acid present in $\mathrm{MO}$ both are monoethenoid acid but there is report that erucic acid may cause some adverse effect in the lipid profile of serum. When MO is blended with EPO (2.5\%) and the rats were fed for 12 weeks, then there is no such elevation in LDL level. This effect may be due to the prolonged effect of GLA on the erucic acid metabolism.

It is known that dietary erucic acid causes cardiac lipidosis. And therefore, generally, oil containing erucic acid is not preferred. In this study, however, erucic acid did not affect heart cholesterol and triglyceride concentrations. It may be that at the present level of dietery erucic acid which is around $10 \%$ there is no development of heart lesion. Although there is a report of development of heart lesion in rats if a diet containing 15\% of erucic-acid rich rapeseed oil (45-50\% erucic acid) was fed to rats ${ }^{20}$.

MO contains (16.60\%) linoleic acid and GNO contains (26.81\%) which is almost 10\% greater than MO. But there is no striking difference in the TG level in MO and GNO fed group as such. So it can be said that increase in the level of linoleic acid does not influence in the TG reducing properties. So a drop in the significant decrease in TG content may be attributed to GLA from EPO in the dietary MO and GNO fed group.

The increase in the linoleic acid content by $3 \%$ in case of 
Effect of $\gamma$-Linolenic Acid on Lipid Profile of Rat

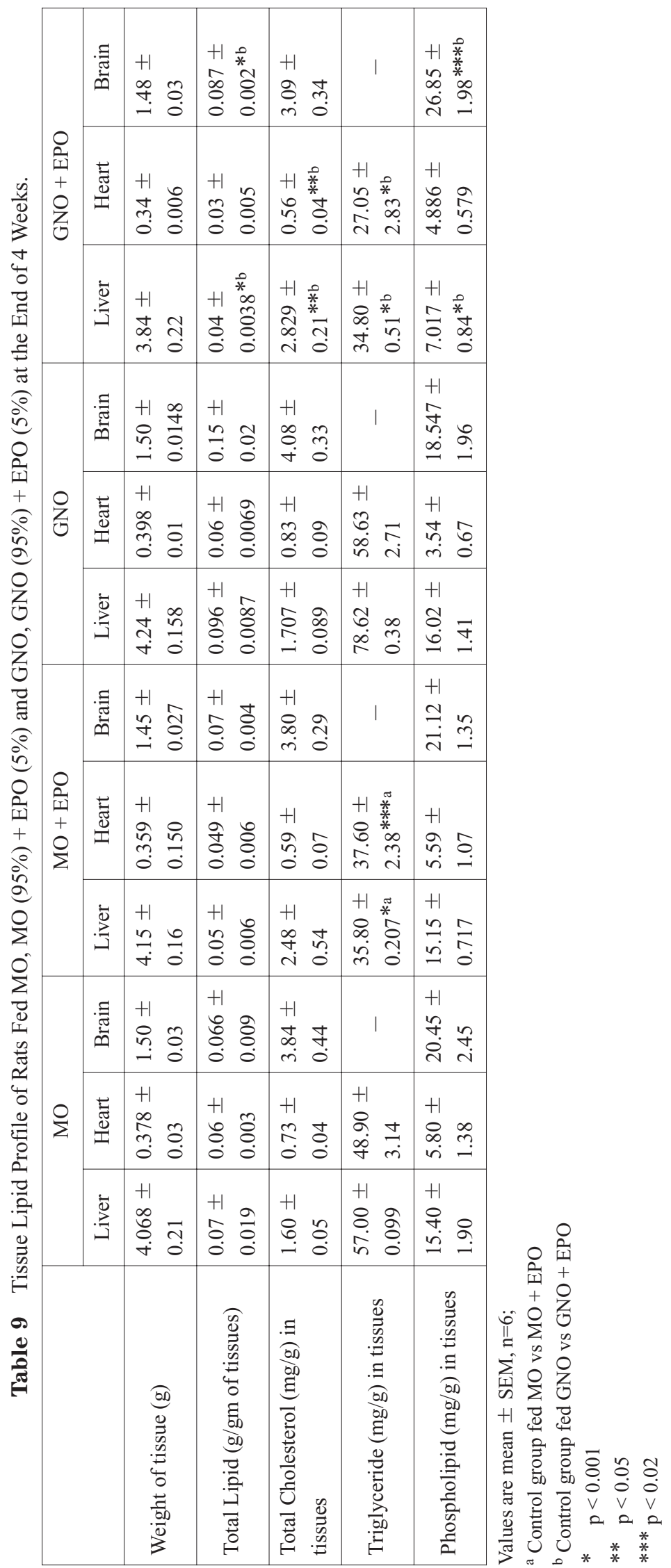


Table 10 Lipid Concentrations of Serum of the Rats Fed MO and MO (97.5\%)+EPO (2.5\%) at the End of 12 Weeks.

\begin{tabular}{|l|c|c|}
\hline & MO & MO + EPO \\
\hline Total cholesterol $(\mathrm{mg} / \mathrm{dl})$ & $58.5 \pm 1.41$ & $60.72 \pm 2.07$ \\
\hline Triglyceride $(\mathrm{mg} / \mathrm{dl})$ & $117.8 \pm 5.44$ & $76.06 \pm 2.46^{* a}$ \\
\hline HDL Cholesterol $(\mathrm{mg} / \mathrm{dl})$ & $28.93 \pm 0.88$ & $39.09 \pm 3.12^{\text {**a }}$ \\
\hline VLDL Cholesterol $(\mathrm{mg} / \mathrm{dl})$ & $23.56 \pm 1.09$ & $14.25 \pm 2.60^{\text {***a }}$ \\
\hline LDL Cholesterol $(\mathrm{mg} / \mathrm{dl})$ & $7.99 \pm 2.06$ & $6.02 \pm 0.86$ \\
\hline
\end{tabular}

Values are mean \pm SEM, $\mathrm{n}=6$

${ }^{\text {a }}$ Control group fed MO vs MO + EPO

* $\mathrm{p}<0.001$

$* * \quad \mathrm{p}<0.02$

$* * * \mathrm{p}<0.01$

Table 11 Tissue Lipid Profile of Rats Fed MO, MO (97.5\%) + EPO (2.5\%) at the End of 12 Weeks.

\begin{tabular}{|l|c|c|c|c|c|c|}
\hline \multirow{2}{*}{} & \multicolumn{2}{|c|}{ MO } & \multicolumn{2}{c|}{ MO + EPO } \\
\cline { 2 - 7 } & Liver & Heart & Brain & Liver & Heart \\
\hline $\begin{array}{l}\text { Weight of tissue } \\
(\mathrm{g})\end{array}$ & $4.87 \pm 0.15$ & $0.58 \pm 0.009$ & $1.43 \pm 0.03$ & $4.81 \pm 0.12$ & $0.54 \pm 0.02$ & $1.43 \pm 0.03$ \\
\hline $\begin{array}{l}\text { Total lipid } \\
\text { (g/gm of } \\
\text { tissues) }\end{array}$ & $0.049 \pm 0.004$ & $0.05 \pm 0.0039$ & $0.067 \pm 0.008$ & $0.046 \pm 0.002$ & $0.03 \pm 0.0048$ & $0.08 \pm 0.004$ \\
\hline $\begin{array}{l}\text { Total } \\
\text { cholesterol } \\
(\mathrm{mg} / \mathrm{g}) \text { in tissues }\end{array}$ & $1.76 \pm 0.31$ & $0.64 \pm 0.14$ & $2.00 \pm 0.24$ & $2.55 \pm 0.12 * * \mathrm{a}$ & $0.569 \pm 0.08$ & $0.49 \pm 0.11^{* a}$ \\
\hline $\begin{array}{l}\text { Triglyceride } \\
(\mathrm{mg} / \mathrm{g}) \text { in tissues }\end{array}$ & $44.53 \pm 3.32$ & $46.82 \pm 3.89$ & - & $39.88 \pm 1.68$ & $24.76 \pm 2.38^{* * * a}$ & \\
\hline $\begin{array}{l}\text { Phospholipid } \\
(\mathrm{mg} / \mathrm{g}) \text { in tissues }\end{array}$ & $4.06 \pm 0.74$ & $1.88 \pm 0.49$ & $27.33 \pm 3.08$ & $4.44 \pm 0.89$ & $1.52 \pm 0.46$ \\
\hline
\end{tabular}

Value are mean \pm SEM, $n=6$

${ }^{\text {a }}$ control group fed MO Vs MO + EPO

* $\quad \mathrm{p}<0.001$

$* * \quad \mathrm{p}<0.05$

$* * * \quad \mathrm{p}<0.02$

$\mathrm{MO}+\mathrm{EPO}(95 \%+5 \%)$ fed group does not appear to influence the TC level in serum of rats. There is significant drop in TG content in case of the EPO + MO blend which is activated to the presence of GLA and not due to linoleic acid content.

The probable mechanism for the reduction of TG in serum of the rats fed GLA may be involved. It could be that dihomogamma-linolenic acid (DGLA) is formed from GLA by the chain elongation process, which in turn through cyclooxygenase pathway produces prostaglandin $\mathrm{E}_{1}\left(\mathrm{PGE}_{1}\right)$ which binds to the G protein coupled surface PGE receptor. The PGE that stimulates in turn adenylate cyclase activity enhances the cellular level of cyclic adenosine monophosphate (cAMP). This increased level of cAMP activates cellular protein kinase which activates the inactive hormone sensitive lipase to active hormone sensitive lipase 
which in turn breaks the TG to glycerol and free fatty $\operatorname{acid}^{21)}$. Thus TG content may be reduced. Increase in HDL cholesterol also results in the increased transport of cholesterol from tissue to liver leading to increased liver cholesterol. Thus dietary GLA appears to have some beneficial effects on controlling the accumulation of TG on serum and other tissues of rat and helps in controlling the cholesterol level of tissues by removing it to liver through increased HDL level.

Thus dietary GLA, irrespective of the nature of monoethenoid acid in dietary oil shows distinct impact on lipid profile of serum and other tissues of rat.

\section{CONCLUSION}

EPO containing GLA when blended with high erucic acid rich MO, provides beneficial effects like the reduction of TG, VLDL and the elevation of the HDL in serum. GLA in addition helps to decrease the level of TG and increase the level of TC in liver and also decrease TG in heart. Similar trend of lipid profile is revealed with higher dose of GLA fed for a short period as with the lower dose of prolonged study. So ingestion of GLA with higher dose for short period may be advantageous for quick beneficial results.

\section{ACKNOWLEDGEMENT}

The study was financially supported by University Grants Commission (Government of India).

\section{References}

1. Ghafoorunissa. Requirements of dietary fats to meet nutritional needs and prevent the risk of atherosclerosis-an Indian perspective. Indian J. Med. Res. 108, 191-202 (1998).

2. Kramer, J.K.G.; Saver, F.D.; Wolynetz, M.S.; Farnworth, E.R.; Johnston, K.M. Effects of dietary saturated fat on erucic acid induced myocardial lipidosis in rats. Lipids 27, 619-623 (1992).

3. Gunstone, F.D.; Harwood, J.L.; Padley, F.B. The lipid handbook, Chapman and Hall, London, pp.173-175 (1994).

4. Kendrick, A.; Ratledge, C. Lipids of selected molds grown for production of $\mathrm{n}-3$ and $\mathrm{n}-6$ polyunsaturated fatty acids. Lipids 27, 15-20 (1992).

5. Suzuki, O. Production of $\gamma$-linolenic acid by fungi and its industrialization, in Proceedings world conference on biotechnology for the fats and oils industry, (Applewhite, T.H. ed.), Am. Oil Chem. Soc., Champaign, pp.110-116 (1988).

6. Barber, A.J. Evening primrose oil: A panacea? Pharmaceut. J. 240, 723-725 (1988).

7. Jantti, J.; Sepala, E.; Vapaatalo, H.; Isomaki, H. Evening primrose oil and olive oil in treatment of rheumatoid arthritis. Arthritis Clin. Rheumatol. 8, 238-244 (1989).

8. Khoo, S.K.; Munro, C.; Battistutta, D. Evening primrose oil and treatment of premenstrual syndrome. $\mathrm{Med}$. J. Australia. 153, 189-192 (1990).

9. Metcalfe, L.D.; Schmitz, A.A. The rapid preparation of fatty acid esters for gas chromatographic analysis. Anal. Chem. 33, 363-364 (1961).

10. Ray, S.; Bhattacharyya, D.K. Comparative nutrition study of enzymatically and chemically interesterified palm oil products. J. Am. Oil. Chem. Soc. 72, 327-330 (1995).

11. Joanes, J.H.; Foster, C.A. Salt mixture for use with basal diet either low or high in phosphorus. J. Nutr. 24, 245-256 (1942).

12. Kates, M. Techniques of lipidology, American Elsevier Publishing Co., New York, pp.349-351 (1972).

13. Allain, C.C.; Poon, L.S.; Chan, C.S.G.; Richmond, W.; Fu, P.C. Enzymatic determination of total serum cholesterol. Clin. Chem. 20, 470-475 (1974).

14. Warnick, G.R.; Nguyen, T.; Albers, A. Comparison of improved methods for quantification of high-density lipoprotein. Clin. Chem. 31, 217-222 (1985).

15. Friedwald, W.T.; Levy, R.I.; Fredrickson, D.S. Estimation of the concentration of low density lipoprotein cholesterol in plasma without use of preparative ultracentrifuge. Clin. Chem. 18, 499-502 (1972).

16. Hatch, F.T.; Lees, R.S. Practical methods for plasma lipoprotein analysis. Adv. Lipid Res. 6, 1-68 (1968).

17. Bucolo, G.; David, M. Quantitative determination of serum triglyceride by the use of enzymes. Clin. Chem. 19, 476-482 (1973).

18. Chen, P.S.; Toribara, T.Y.; Warner, H. Micro determination of phosphorous. Anal. Chem. 28, 1756-1758 (1956).

19. Pearson, S.; Hartley, H.O. eds., Biometrica tables for statisticians 1, Cambridge (1966).

20. Chakraborty, M.M. Safety of specific acids in Chemistry and technology of oils and fats (Allied Publishers Pvt. Limited) New Delhi, pp 121 (2003).

21. Mayes, P.A. Lipid transport and storage in Harper's biochemistry (Murray, R.K.; Granner, D.K.; Mayes, P.A.; Rodwell, V.W. eds.) $25^{\text {th }}$ edition, Appleton and Large, Stamford, Connecticut, pp 280-282 (2000). 